\title{
Perceived Impact of the Alqueva Dam on Regional Tourism Development
}

\begin{abstract}
The paper studies the impact of the Alqueva Multi-Purpose Dam on the Alentejo region (Portugal), focusing on tourism development. In 2002, the Alqueva dam originated the largest artificial lake in Europe and was widely believed to bring a great number of benefits for the region by creating conditions for intensive irrigated farming and enhance a new tourism destination in interior Portugal. The aim of this study is to assess in what degree the latter has been achieved. Interviews were held with 35 local and regional stakeholders of the tourism andheritage sectors to understand their perception regarding the changes occurred in the regional tourism industry since the dam's construction. Findings show that, against all expectations, the tourism industry is still largely underdeveloped, partly due to a lack of investment and an inadequate tourism planning model. Furthermore, conflicts were observed concerning the balance between the value of the traditional montado landscape for tourism and irrigated farming development.
\end{abstract}

Keywords: Alqueva dam; rural tourism; regional tourism development; stakeholder perception

\section{Introduction}

The use of water by means of damming rivers has been happening for thousands of years. The benefits that result from the construction of dams are diverse, such as the provision of water and electricity in the long term, as well as opportunities for new economic activities and job creation. Other side benefits that often occur are improved conditions for inland navigation, tourism development or aquaculture, although only $5 \%$ of worldwide dam projects consider these objectives in the planning stage (WCD, 2000).

On the other hand, the installation of dams entails a number of negative consequences, such as the physical transformation of rivers and their natural flow, the profound shock imposed on the river basin ecosystems and human communities that live on its banks, and the loss of cultural heritage such as archaeological remains (Égré \& Senécal, 2012; WCD, 2000).

The paper is part of a broader research project ${ }^{1}$ which aims to study the potential of the archaeological heritage uncovered during the environmental impact assessment of the Alqueva dam construction to complement the tourism experience that the region currently offers (XXXXXX, 2014) (reference omitted for blind review). However, as the research progressed, questions arose concerning the evolution of the regional tourism sector in light of the recent installation of the Alqueva dam, one of the largest public works of the twentieth century in Portugal. The expectations generated by the potential that this enterprise poses to regional

\footnotetext{
${ }^{1} \ll X X X X X X X X X »$ (omitted for blind review).
} 
development are high, therefore the purpose of this paper is to understand the perception of regional tourism stakeholders concerning the development of the Alqueva tourism destination after the completion of the dam.

To this end, 35 semi-structured interviews were held with local and regional tourism and heritage actors in order to gather their impressions and opinions about the changes occurred since the closure of the floodgates in 2002, namely: change of tourists' expectations and motives to visit the region; the diversification of tourism products and services given the onset of the Great Lake of Alqueva; and how the dam has affected tourism development in the region.

The paper begins by presenting the Alqueva Multi-Purpose Dam case and some of the issues present in the debate that relates dams and regional development. A description of the applied methodology follows. The findings are then presented and discussed, after which the article is concluded.

\section{Dams and Regional Development}

The development of large dams is often backed by the argument that these projects are able of creating value from the wilderness, so that "in order for large hydroelectric projects to make sense, water resources such as rivers and lakes in their natural state have to be regarded as having no monetary value" (Rosenberg, Bodaly, \& Usher, 1995, p. 147).

With regard to tourism development in sites where dams have been installed, the appearance of a water reservoir, whether with the purpose of producing hydroelectric power or agricultural irrigation, irreversibly alters the landscape and creates a new feature that enables the realization of, for example, nautical activities where previously it was not possible. However, in these cases tourism development is frequently associated as a secondary benefit which can accrue from the enterprise, and as such is often defended by maximizing positive impacts in disregard to negative impacts (Ferreiro et al., 2013).

Moreover, there are many cases which show that despite predicted benefits, regional development plans and investment promises made, dam infrastructures per se are not always necessarily able to foster regional development (Al-Kheder et al., 2010; WCD, 2000). Rosenberg et al. (1995, p. 143) addressed some common misunderstandings about the notion that large dams benefit local communities. For instance, the authors show that the development of water retaining infrastructures in the Canadian Shield region completely changed the economic system of the local Cree Indian communities with heavy implications on their social lives and impoverishment. On a more positive note, the thousands of Nubians relocated by consequence of the Aswan Dam, in Egypt, did manage to develop their handicraft industry directly related to tourism, although their agricultural production did not improve significantly after the dam's construction (Rosenberg et al., 1995, p. 144). Nevertheless, the issues concerning dam development impacts vary greatly according to the geographic and historical context and these become more visible when assessing the impacts of a large dam project in the western countries or in the developing world (Biswas \& Tortajada, 2001). The USA alone, which has completed its 
main dam construction program, produces six times more hydro-electric power than the whole of Africa, where most water sources remain unexplored (Altinbilek, 2002).

In the recent decades, Portugal has had several episodes related to large dam implementation. During the 1990s a heated debate occurred regarding the dam proposed for the mouth of the Côa River, in the northern part of the country. After the discovery during the environmental impact assessment of a set of Paleolithic rock engravings in the Côa Valley which would be submerged by the reservoir, a nationwide broadcasted debate was started between the parties who advocated the construction of the dam and those who defended the preservation and tourism valorisation of the engravings in situ. The huge pressure led to the opposition party's candidate in the 1995 parliamentary elections to take a stance against the construction of the Côa dam and, after winning the elections, the party withdrew the project and aborted its construction (Ferreiro, Gonçalves, \& Costa, 2013). Shortly thereafter, the Côa Valley was listed by the UNESCO as a World Heritage Site in 1998, in what was the quickest procedure ever for a World Heritage Site classification.

More recently, also in the North of Portugal, the case of the Tua dam took different contours. This project is currently under construction despite great protest by environmental NGOs concerned about the negative impacts of the dam, namely the destruction of the river ecosystem and the submersion of the centenary Tua railway line. The dam project furthermore threatens the Douro Valley's classification as a World Heritage Site, even though later UNESCO ultimately reacted favourably to the construction of the dam albeit under certain conditions (UNESCO/ICOMOS/AHFT, 2012). Thus the construction work proceeds under the premise that the lake created will boost regional socio-economic development and create new opportunities for exploitation of nature tourism, nautical tourism, health and wellness and cultural tourism in the local villages.

The implementation of large development projects can create conflicts concerning land use, and this is especially so for the impacts of dams (Namy, 2007) so an assessment of the impact that large development projects can have on the tourism industry is a necessity (Saeporsdottir, 2012). It should be noted that a multi-purpose dam may result in conflicts between the various purposes to the extent that these form a system where all are interlinked and affect each other mutually (Efstratiadis \& Hadjibiros, 2011; Heller, Bollaert \& Schleiss, 2010). Therefore it becomes necessary to consider the integration and co-dependence of various development objectives in the dam's management in order to achieve a balance and harmony between the different purposes, whether these are the irrigation system, reservoir management, electrical power production and/or tourism development.

Furthermore, conflicts can also arise among the stakeholders that use the dam. Kpéra et al. (2012) research led in Benin shows the wide range of interests of the diverse stakeholders that are dependent of the local dams, such as herders, fishermen, farmers, and the crocodiles that live in the area. These conflicts affect the development and management of the dam and can decrease the water quality and overall dam experience. 


\section{The Alentejo and the Alqueva Multi-Purpose Dam}

The Alentejo region is located in the south of Portugal, covering approximately a third of the national mainland territory and includes the districts of Beja, Évora and Portalegre. Despite this great extension, the region accounts for only $7 \%$ of the total population of the country, and furthermore lost $2.5 \%$ of its population in the period between 2001-11 (INE, 2012). In addition to the low population density, the region has the highest aging rates of Portugal, and the GDP values per capita are lower than the national average given the weak business environment (INE, 2012), which can affect the development of the regional tourism industry (Fleischer \& Felsenstein, 2000; Ribeiro \& Marques, 2002).

These data reflect a historical trend of the Alentejo, where the low rainfall and open plains condition the agricultural practice traditionally governed around large estates, which in turn motivates high population dispersion (GPAa, 2005). This framework, coupled with a set of historical, political and economic factors contributed to the concentration of power and wealth within small elite groups and the territorial planning to be made centred around large poles designed to lead and support the region's development (Veiga, Duarte \& Vasconcelos, 2008). This tendency to centralize can be presently observed in the so-called development triangle comprised by the Sines Harbor, the Beja Airport and the Alqueva Dam, the three pillars upon which rest the development discourse of the Alentejo.

The Alqueva Multi-Purpose Dam (EFMA) project emerged in 1957 with the drafting of the Alentejo Irrigation Plan, which aimed at improving the farming conditions in this region historically affected by drought. Following four decades of successive studies and setbacks, the dam construction finally began in 1998 and the floodgates were closed in 2002, creating the largest artificial lake in Europe which covers $250 \mathrm{~km}^{2}$. Furthermore, the irrigation system currently under construction will provide water for 120,000 hectares (Figure 1). It is considered by many to be the most iconic and controversial national building work of the twentieth century for several reasons: the dragging of the process for several decades; the successive environmental impact studies and opposition by environmental groups due to the expected environmental and social impacts; the huge public investment it required and the expected return; and the extensive media coverage that attracted attention from all over the country (Melo, 2009). For these reasons, the Alqueva dam became a national myth impossible to challenge and to ignore in the public sphere (Baptista \& Vasconcelos, 2005), with political and ideological contours which led to the diffusion of a real "alquevization" mentality in Portugal (Veiga et al., 2008, p. 3).

The main purpose of the EFMA is to establish a water supply capable of meeting the agricultural needs of a wide area of the Alentejo and carry water away from the banks of the reservoir to the areas with the most fertile soils (RCM n $\left.{ }^{\circ} 70-2002\right)$. Besides irrigation and hydropower production, the EFMA also includes a program of socio-economic development which assumes the tourism activity as a way to take advantage and make the most of the inevitable landscape transformation and distinctiveness that the Great Lake of Alqueva has brought to the region (Marujo, 2005; Rodrigues, 2007). 
In the Alentejo, the traditional silvo-pastoral landscape locally known as montado is a structural part of the regional identity, occupying over 730.000 hectares of the region (PintoCorreia, Ribeiro, \& Sá-Sousa, 2011). Know in Spain as dehesa, this kind of countryside is common in most Mediterranean countries. Characterized by its "savanna-like physiognomy" (idem, p. 100), the multifunctional montado landscape is of great economic value, which extends also to the environmental, cultural and touristic value as well. The image of the golden plains with scattered holm oak and cork trees is the Alentejo's most popular postcard picture and is strongly associated with the rural country life of the local towns and communities. However, the montado is a very fragile ecosystem, and given the multitude of uses that it serves requires specific management measures in order to harness its preservation and development (PintoCorreia \& Vos, 2004). With the onset of the Alqueva dam which is expected to bring irrigation to 120.000 hectares by 2015 , the montado is under pressure and a large parcel of it will eventually disappear as a consequence of the shift in agricultural practice, consequently affecting the touristic value of the region (Arvela et al., 2012; Marujo, 2005). As a reaction, the regional tourism authorities have recently begun working on an application of the montado to UNESCO World Heritage status in order to preserve some patches of this particular landscape.

Moreover, acknowledging that the development of leisure tourism does not spontaneously result of the installation of a dam, in 2002 the Regional Plan of the Alqueva Reservoir Shoreline (PROZEA) was drafted with the aim to define a framework for economic development in the area surrounding the reservoir ( $\mathrm{RCM} \mathrm{n}^{\circ} 70-2002$, p. 3398). Furthermore, the Great Lake of Alqueva's potential in the national tourism context was formalized at the political level by the national tourism authorities (Turismo de Portugal, 2007) in the National Strategic Plan for Tourism (PENT) which, in recognition of the potential of this region, created a specific management body for the destination. However, the difficult economic and financial situation that the country entered led to the extinction of this organization, integrating it into the broader Alentejo Regional Tourism Authority. The same happened to Gestalqueva, a regional body which associated the Alqueva dam developers with the City Councils of the regional municipalities with the purpose of promoting tourism in the Great Lake surroundings.

The tourism expectations generated around the Great Lake of Alqueva and the political support from the Portuguese Government of that time attracted a number of large Portuguese economic groups to the possibility of developing real estate projects which, due to their huge dimension, were designated as projects of Potential National Interest (PNI). Most of these projects consisted of high-quality accommodation units to be installed on the shores of the Great Lake, with tens of thousands of beds and seven golf courses approved. Of these, only one began construction, although in 2012 it went into insolvency due to the lack of credit (Ferreira, 2012), and so is currently suspended.

In 2009 the Alqueva registered discouraging values at the national level concerning the destination branding attractiveness, revealing that the domestic market - which makes up approximately $70 \%$ of the Alentejo's tourism market - is mostly ignorant about the Alqueva as a touristic option, therefore it is premature to assume the region as a tourism destination (Brandia 
Central, 2009). In this study the Alqueva was given the lowest rating out of all the tourism regions of Portugal, which is consistent with the national tourism framework, in which the Alentejo is the region with the lowest expression in mainland Portugal, registering only $2,9 \%$ of the total national share of overnight stays (INE, 2013). These results can be traced back to some of the challenges presented by Ribeiro \& Marques (2002) which relate low population density in rural areas with the development of tourism activities. Finally, a study carried out at the local level among residents and parish presidents of several Great Lake coastal villages to determine the impacts felt shows that in 2009, despite a number of interviewees and respondents still maintained positive expectations and hope in the dam, the projected benefits were not yet visible (Tedim, Sullivan, \& Estrela, 2009).

\section{Methods}

The present study was based on a qualitative method in which semi-directed interviews were held with various tourism and heritage stakeholders in the Alqueva region.

\section{Sampling}

Data were collected from the work undergone in the broader research project previously mentioned. Given the extent of the Alentejo, and based on the objectives of this study, the authors decided to limit the data collection to three counties located near the dam, namely Serpa, Moura and Vidigueira.

The sampling of stakeholders was based on the Andalusia tourism cluster map (LastraAnadón et al., 2011), assuming a similar tourism framework in the Alentejo region, and included players of the regional and local scope. Representatives of local public authorities and private sector companies, as well as stakeholders involved in the management of cultural heritage were interviewed. In addition, some stakeholders located in other municipalities were interviewed, such as regional tourism and cultural and natural heritage authorities based in other counties, and owners/managers of relevant tourism projects focused on the archaeological heritage of the Alentejo. In total, 35 stakeholders were interviewed between February and May 2013.

\begin{tabular}{|c|c|c|}
\hline & Stakeholder category & $\mathrm{N}^{\mathrm{o}}$ of stakeholders interviewed \\
\hline & $\begin{array}{l}\text { Regional scope } \\
\text { Tourism authorities } \\
\text { Regional development authorities } \\
\text { Cultural/natural heritage authorities }\end{array}$ & $\begin{array}{l}3 \\
2 \\
3\end{array}$ \\
\hline Public & $\begin{array}{l}\text { Local scope } \\
\text { Museums } \\
\text { Cultural associations } \\
\text { Schools } \\
\text { City councils } \\
\text { Parish councils }\end{array}$ & $\begin{array}{c}3 * \\
3 * \\
3 \\
3 * \\
2\end{array}$ \\
\hline
\end{tabular}




\begin{tabular}{|c|l|c|}
\hline \multirow{4}{*}{ Private } & Hotels & 3 \\
& Restaurants & 3 \\
& Tourism recreation & 3 \\
& Handcrafts & 3 \\
& Farmers/producers & $5^{*}$ \\
\hline \multicolumn{2}{|c|}{ Note: interviews marked * were held with people who represent two stakeholder organizations, } \\
so are counted twice. (Vidigueira's City Council and museum; local association Serpa and \\
Moura; Serpa's City Council and museum; Vidigueira's producers and local association) \\
\hline
\end{tabular}

\section{Instruments and Procedures}

The interview guide was based on the qualitative study by Morgan, Elbe, \& Curiel (2009), who studied the perception of tourism stakeholders regarding the tourist experience at three European destinations. The aim of the interview was to understand the view that the respondents have about the Alqueva destination and the changes which have occurred in the tourism sector following the construction of the dam and filling of the reservoir. The interview guide was based on the following questions:

- How do you describe the Alqueva region and your county as a tourism destination? What are in your opinion the most iconic and popular tourism products and services?

- Have you noticed any change in the regional tourism market after the inauguration of the Alqueva dam (e.g. new products and/or events, or the decline of previously existing ones)?

- Do you notice any difference concerning the tourists' expectation before and after Alqueva dam? Do you think the reasons for visiting this destination have changed?

- How do you see the future of the region as a tourism destination? Do you think that the tourism products and supply will change?

\section{Data Processing and Content Analysis}

All interviews were audio-recorded and transcribed, and the MAXQDA 11 software was used to assist in the data organization and content analysis. The categories that resulted from the interpretation of the data were obtained through a process of axial coding based on the interview questions (Saldaña, 2009).

\section{Results}

\section{Tourism in Alqueva}

Tourism in the Alqueva region has always been associated to the rural environment, where cultural and scenic touring through the montado landscape assumes a leading role. According to the stakeholders interviewed, the most relevant resources and tourism products in the region are food and wine (and derived products: fairs, wine routes, etc.) $(n=12)$, the built heritage and museums (cultural tourism) $(n=9)$, handcrafts $(n=4)$, the Alentejo countryside and the rural 
environment $(n=4)$, and house-boats/boat-rides and nautical activities $(n=3)$. Hunting tourism $(\mathrm{n}=1)$, birdwatching $(\mathrm{n}=1)$, and active and nature tourism $(\mathrm{n}=1)$ were rarely referred, despite the region's potential for these kind of activities.

\section{Impact of the Dam}

Four respondents referred that prior to construction of the Alqueva dam, the region was not outstanding in any particular aspect and to visitors it was similar to the rest of the interior Alentejo, i.e., montado landscape. However, the appearance of the dam and the Great Lake came to change the way the planning and development of the territory are done. A businesswoman stated that this region can now be considered a tourism destination according to the World Tourism Organization definition. Five stakeholders mentioned that the dam is a structuring element for the tourism sector in Alentejo.

\footnotetext{
"Alqueva [dam] today is a structuring element to any approach that can be done for the development of the region. Be it from an economic point of view or the social point of view, it is considered an essential element. It is not possible to think of any local and regional development strategy without Alqueva and so today it is already a reference." (interview \#29 - director of professional school)
}

The tourism authorities of the region, on the other hand, argued that although the region has gained extensive visibility there is still a lot of work to be done before it can become marketable. According to this stakeholder, the industry is currently underdeveloped, which is visible in the region's limited accommodation capacity, for example.

Three other respondents were not convinced of the Alqueva dam's tourism potential, referring to similar dam projects where tourism development did not occur, and a sense of shattered expectations was referred to regarding the dam.

\footnotetext{
"I do not even know if there is much tourism potential of the Great Lake except for very specific aspects related to nautical sports tourism, sports fishing championships, because you don't see much more than that. Even the boat rides, I have the impression that it is something that is starting to become saturated, and I don't see that there is a great opportunity here or that there was a positive development. But that is common to all dams, if you look at all the dams that have been done in our country there is always this idea that they will provide general support to economic development, to tourism, this and that and then excluding some exceptional cases, this has not happened." (interview \#9 - director of natural heritage managing entity)
}

\section{Variation in Demand and Expectations}

Some stakeholders $(n=8)$ stated that there was an increase in tourism demand following the inauguration of the dam. On the other hand, the majority $(n=22)$ reported that, excluding the excursionists that visit to see the dam, there was not a continued increase in tourists visiting the 
region after the completion of the building work. According to the stakeholders, these daytrippers contribute little to the tourism sector and, although they can benefit the restaurant sector or occasionally participate in tourism entertainment activities, it is not a sustained demand and is not enough to ensure the strengthening of the regional economy and businesses, in particular hotels and other accommodation businesses.

\footnotetext{
"You see tourists now these days when the dam is discharging. It is a pilgrimage, but it's just people going on a late afternoon ride.” (interview \#25 - craftsman)

"We were very expectant about the consequences that the opening of the dam would bring but in fact we have not seen any changes since the dam was completed. (...) Personally, I had expectations that people who visited the dam, being just 9 or 10 kilometres away, would come looking for the nearest urban centre and explore it from the point of view of tourism but actually that has not happened at all." (interview \#17 - director of museum)
}

\section{Diversification of Tourism Supply}

The onset of the Great Lake does not seem to have been strong enough to stimulate the diversification of tourism products and services. In this sense, an exception mentioned $(n=7)$ is the Amieira Marina rental operator, whose supply of boat rides and houseboats has become a reference in the region. Another relevant example is the Dark Sky Alqueva, an astrotourism project that involves a small network of private tourism companies and some institutional players. Although not directly related to the dam, this project was somehow driven by the dynamics and expectations that the enterprise stirred in regional tourism. However, it is still at an early stage of development and therefore has not yet consolidated as a tourism product $(\mathrm{n}=2)$.

"The Alqueva before filling the reservoir had almost nothing and after filling it still has almost nothing in terms of tourism." (interview \#13 - president of business association)

"It actually operated a brutal transformation. (...) The point is that this did not (...), to the degree that one would think, did not bring a diversification of the tourism supply. Just realize that, strictly speaking, there is only one tourist equipment post-filling of the dam which is the Amieira Marina rental operator. That is, if we look at what was the tourism system of that territory before the dam filling, and if we look at what we have today on May 2, 2013, strictly speaking, in short, from the point of view of tourism there are some piers, obviously one or two players have appeared who began developing nautical tourism activities, two or three new restaurants may have appeared, but the tourism dynamics of that territory is unable to establish a link of cause-effect with the filling of the dam, with the exception of the Amieira Marina, which is in fact a structuring player that indeed stands out from the other water-touring operators from other areas of Alentejo." (interview \#34 - tourism authorities representative) 
The problems that affect the region and its tourism development most frequently mentioned in the interviews were the lack of infrastructure $(n=10)$ (lack of accommodation capacity, of piers to support nautical and leisure beach activities), desertification due to demographic exodus $(\mathrm{n}=6)$ and an aging population $(n=3)$, poor quality of the reservoir water $(n=3)$, a weak regional business network $(n=2)$ and the current economic crisis $(n=2)$. These latter are issues that affect not only the tourism industry but are consequence of a broader structural tendency common to most of the Portuguese hinterland.

According to a few interviewees $(n=3)$, the low tourism supply and demand in Alqueva is a result of the wrong strategic decisions and lack of public investment in tourism infrastructure, namely to support nautical activities (piers, etc.), which creates additional difficulties for the private actors to develop their activity.

\section{Potential National Interest (PNI) Projects}

The tourism development plan based on the Alqueva PNI projects was sometimes referred to in the interviews. Three respondents showed some concern that the cancellation of these mega-PNI projects will affect tourism development, stating that these projects could increase the attractiveness of the destination, boost the local economy and create new investment and job opportunities.

On the other hand, seven other stakeholders (some of which working for institutions related to the cultural and natural heritage) argued that these projects do not take into account the needs and socio-cultural and economic characteristics of the region and that their cancellation is positive because it will allow to re-evaluate the tourism development model designed for the region. These argued that planning should focus on the qualification and improvement of that what already exists, complementing between the various products and resources of the territory rather than contributing to create more supply, a view also shared by the regional tourism authorities.

"The large tourism projects that were announced were, as confirmed now, completely speculative and unrealistic. It was always the same model: a large golf course, a large hotel property, and residential tourism homes around the golf field. For those familiar with the climate of the Alentejo and that area, I always thought someone should be delirious because I would never buy a house just because there is water there." (interview \#14 cultural heritage officer)

"Nothing happened and nothing will happen because the tourism development model that is planned for the banks of Alqueva is a completely inappropriate and inadequate development model of what is necessary." (interview \#12 - local administration officer) 
The tourism authorities seem to argue against any criticism to the original model, claiming that the problem was a lack of organization among stakeholders in order to successfully execute the planned model.

\footnotetext{
"And we had a very important thing which is rare in Portugal: is that before that dam, before the lake filled, before filling the reservoir there was already a Regional Spatial Plan. This in 2005, which in Portugal is a very rare thing - we usually always walk backwards. But even so we did not manage to move forward in an organized, integrated, systematic way so that today after almost nine years there could be something more consolidated than what there is because what we currently have is in fact very short." (interview \#34 - tourism authorities representative)
}

\section{Landscape Transformation}

Five stakeholders mentioned that the greatest impact of the dam to date can be seen in the agricultural sector, as was predicted, and that the region's future is inextricably linked to this sector, whose development ultimately affects all other sectors. Indeed, agricultural activity in this region is in an early stage of a profound transition process to the predominance of irrigated farming. Four respondents showed some concern about the effect that this new agro-industrial model led by large companies is likely to have on tourism, stating that the change brought about in the landscape may be incompatible with the type of tourism based on products and services whose value lies in the rural imaginary of the Alentejo's montado landscape.

"I then start to think 'are 20 hectares of potato fields compatible with high-quality niche tourism where for example archaeology is included?', and I cannot answer that." (interview \#33 - wine producer)

Others referred to this transformation as an opportunity for new developments regarding the region's marketing and tourism industry.

\footnotetext{
"The one thing that Alqueva has changed is the very landscape of the Alentejo. The Alentejo today is not the same, which means there's a big job to be done which is to change this idea that people still have of the Alentejo. (...) That's where there is a big job to be done and we - not only the Alentejo, but the Portuguese in general - we are a bit weak in this part of marketing. We have good things and don't know how to sell them and have difficulty in demonstrating. We are a little embarrassed. The Alentejo in this respect, what the Alqueva, just by all that water being there, changed in terms of possibilities of territorial marketing and image of the region is not yet explored... I would say that it is 5 on a scale from 0 to 100. And the impact that Alqueva can have for example on these aspects of tourism is the same thing." (interview \#11 - regional development institution officer)
}

\section{Discussion}


There is no doubt that the dam and the Great Lake have become elements of undeniable interest to everybody that visits the Alqueva region. However, the findings of the interviews show that most visitors are mainly driven by curiosity to contemplate the building work finally completed rather than for tourism purposes. In this sense it is clear that the Alqueva region is currently far from being a fully operating tourism destination, a conclusion supported by the low demand and lack of nationwide visibility (Brandia Central, 2009).

As such, it is relevant to examine other cases in Portugal where large dams have been implemented. A study undertaken in the Trás-os-Montes region (northern Portugal) shows that the average unemployment and desertification rates are higher precisely in the municipalities of the region where dams for hydroelectric power have been built, and that these counties even register a lower average of overnight stays than those where there are no dams (Simão, 2009). In the Alqueva region, this inability to attract tourists can be partly explained due to the shortage of products and services available in the market. This issue can also be related to the lack of public intervention in creating basic infrastructure able to support tourism activity which affects the development of the sector and private investment by tourism businesses. In this respect, despite the National Strategic Plan of Tourism (Turismo de Portugal, 2007) having pointed out the Alqueva as a high-priority potential destination and that its development should focus on the promotion of nautical tourism activities, among others, the results hereby presented indicate that public investment to enable the exploration of this type of product fell short of what was needed, in the line of the research by Nash \& Martin (2003).

On the other hand, the referred strategic planning based on large Potential National projects (PNI) focused on residential tourism proved to be a failed strategy, although this is not oblivious to the difficult circumstances that affect the national economy. As Neto (2013, p. 56) refers: "the Alentejo is perhaps one of the greatest victims of the wrong official policy options and of the mystifying and irresponsible demagoguery of the last decade". In the Jordan Valley (Jordan), a region which as the Alentejo is rich in archaeological heritage and where were built large hydroelectric projects, there were similar problems that affected sustainable tourism development, mainly due to the lack of efficient strategic planning, as pointed out by Al-Kheder et al. (2010).

In this sense, the present study also shows that a part of local actors consider the original tourism development model, based upon mega-residential tourism projects, to be inappropriate, whereby the support of smaller local initiatives seems to be the most adequate approach as demonstrated by the success of the Dark Sky Alqueva and Amieira Marina cases. Such evidence can be strengthened when it is noted that these projects show encouraging results: the Amieira Marina boat rental has consolidated and become a structuring product for the region and the Dark Sky Alqueva, albeit recent, has gained visibility due to international recognition and awards that indicate a promising future. However, taking into account the potential of the Great Lake, the success of these two cases is not sufficient to meet the expectations generated by the dam. 
One should note that of the multiple purposes that the EFMA project comprises, the one that so far has translated best effective results is the agricultural sector. The water reservoir created by the dam and the irrigation system under implementation have opened new opportunities for agricultural development, addressing that which was until recently the biggest predicament of this territory.

However, there is awareness among tourism stakeholders that the typical montado scenery will gradually disappear due to the change in farming practice, and that this traditional rural imagery is an essential element of attraction for those looking for an immersive experience in the rural environment. The cultural and landscape touring, that is, the organization of circuits and thematic routes (i.e. Wine Route) is the main product and reason for visiting the Alentejo (Turismo de Portugal, 2013), as the official documents and several interviewed stakeholders both refer. With the introduction of irrigated agriculture in place of the traditional dryland farming and the landscape transformation that will inevitably proceed, a gap will develop between the real landscape and the stereotypes that form the collective imagery which urges rectification (Marujo, 2005).

For such, it is necessary to act hastily to address this gap taking into account the specific needs of all the stakeholders of the region in order to achieve a balance among the various purposes that the Alqueva dam serves (Efstratiadis \& Hadjibiros, 2011; Kpéra et al., 2012).

\section{Conclusion}

This study aimed to evaluate the perception of regional stakeholders in relation to the effects felt in the tourism industry of the Alentejo region following the inauguration of the Alqueva dam. The results of the interviews show that, 12 years passed, there are no major changes in the regional tourism industry, contrary to what was expected and projected (Marujo, 2005; Rodrigues, 2007; Turismo de Portugal, 2007), which proves the findings of some studies conducted over the past few years in the region.

The objectives of agricultural development and hydropower production are nearing completion and observed with interest. However, there is an associated concern about the coexistence of intensive irrigated farming and high-quality rural tourism. Other benefits projected for tourism development have been slow to materialize and a shift in strategic focus is regarded as necessary bearing in mind the challenges common to this kind of regions, i.e. the lack of public investment in infrastructure (Canalejo, 2010; Nash and Martin, 2003). In addition to improving the supply of products directly related to the Great Lake and support for regional development projects, as demonstrated to be the most adequate for this territory, it becomes necessary to develop a preparation work in order to assist the transition of the tourist imagery and public perception considering the two groups of elements: the rural elements, i.e. montado, which currently constitute reason to visit the Alentejo, and the new elements that the region will gain after the irrigation system is fully implemented. 
We hope that this study will contribute to the management of the underlying issues concerning the multiple purposes of the Alqueva enterprise in order to better achieve the goals initially set out.

\section{References}

1. Altinbilek, D. (2002). The role of dams in development. Water Resources Development, 18 (1), 9-24. doi:10.1080/07900620220121620

2. Al-Kheder, S., Haddad, N., Jaber, M.A., Al-Shawabkeh, Y., \& Fakhoury, L. (2010). Sociospatial planning problems within Jordan Valley, Jordan: obstacles to sustainable tourism development. Tourism and Hospitality Planning \& Development, 7 (4), 353-378. doi:10.1080/1479053X.2010.520464

3. Aprovação do Plano Regional de Ordenamento do Território da Zona Envolvente da Albufeira do Alqueva (PROZEA) [Approval of the Regional Plan of the Alqueva Reservoir Shoreline], Resolução de Conselho de Ministros no 70 / 2002 de 2 de Agosto.

4. Arvela, A.S., Panagopoulos, T., Cakula, A., Ferreira, V., \& Azevedo, J.C. (2012). Analysis of landscape change following the construction of the Alqueva dam, southern Portugal Approach and methods. In J. Burley, L. Loures \& T. Panagopoulos (Eds.), Recent Researches in Environmental Science \& Landscaping (pp. 42-47). Faro, Portugal: Wseas Press.

5. Baptista, I., \& Vasconcelos, L. (2005). Muddling through complex contexts: making sense out of a myth. Antropológicas, 9, 97-119.

6. Brandia Central. (2009). Estudo de avaliação da atratividade dos destinos turísticos de Portugal - Alqueva [Evaluation Study of the Attractiveness of the Tourist Destinations in Portugal - Alqueva]. Retrieved from http://www.turismodeportugal.pt/Portugu\%C3\%AAs/ProTurismo/destinos/destinostur\%C3\% ADsticos/Anexos/Alqueva.pdf

7. Biswas, A.K \& Tortajada, C. (2001). Development and large dams: a global perspective. Water Resources Management, 17 (1), 9-21. doi:10.1080/07900620120025024

8. Canalejo A.M.C. (2010). El turismo industrial minero como motor de desarrollo en áreas geográficas en declive. Un estudio de caso. Estudios y Perspectivas en Turismo, 19, 382-393.

9. XXXXXXXXXX (2014). (reference omitted for blind review).

10. EDIA, S.A. (n.d.). Mapa de localização [Location map]. Retrieved May 28, 2013, from http://www.edia.pt/edia/index.php/o-empreendimento/mapa-de-localizacao.

11. Efstratiadis, A., \& Hadjibiros, K. (2011). Can an environment-friendly management policy improve the overall performance of an artificial lake? Analysis of a multipurpose dam in Greece. Environmental Science \& Policy, 14, 1151-1162. doi:10.1016/j.envsci.2011.06.001

12. Égré, D., \& Senécal, P. (2012). Social impact assessments of large dams throughout the world: lessons learned over two decades. Impact Assessment and Project Appraisal, 21 (3), 215-224. doi:10.3152/147154603781766310

13. Ferreira, C. (2012, Agosto 8). CGD atira para a falência projecto no Alqueva considerado pelo Governo de "interesse nacional" [CGD pushes Alqueva project considered by the government to be of "national interest" into bankruptcy]. Público. Retrieved from http://www.publico.pt 
14. Ferreiro, M. F., Gonçalves, M. E., \& Costa, A. (2013). Conflicting values and public decision: the Foz Côa case. Ecological Economics, 86, 129-135. doi:10.1016/j.ecolecon.2012.10.006

15. Fleischer, A. \& Felsenstein, D. (2000). Support for rural tourism. Does it make a difference?. Annals of Tourism Research, 27 (4), 1007-1024.

16. GPAa - Grupo de Projecto Alqueva Agrícola. (2005). Plano de intervenção para a zona do Alqueva (Tomo 2): caracterização da zona de Alqueva [Intervention plan for the Alqueva area (Vol. 2): characterization of the Alqueva area]. Ministério da Agricultura, do Desenvolvimento Rural e das Pescas. Retrieved from http://sir.dgadr.pt/conteudos/gpaa/tomos/tomo_2.pdf

17. Heller, P., Bollaert, E., \& Schleiss, A. (2010). Comprehensive system analysis of a multipurpose run-of-river power plant with holistic qualitative assessment. International Journal of River Basin Management, 8 (3-4), 295-304. doi:10.1080/15715124.2010.517672

18. INE - Instituto Nacional de Estatística. (2012). Censos 2011 Resultados Definitivos - Região Alentejo [2011 Census Definitive Results - Alentejo Region]. Lisbon, Portugal: INE I.P.

19. INE - Instituto Nacional de Estatística. (2013). Statistical Yearbook of Alentejo Region 2012. Lisbon, Portugal: INE I.P.

20. Kpéra, G.N., Aarts, N., Saidou, A., Tossou, R.C., Eilers, C.M., Mensah, G.A., Sinsin, B.A., Kossou, D.K., \& van der Zijpp, A.J. (2012). Management of agro-pastoral dams in Benin: stakeholders, institutions and rehabilitation research. NJAS - Wageningen Journal of Life Sciences, 60-63, 79-90. doi:10.1016/j.njas.2012.06.011

21. Lastra-Anadón, C., Dias, J. N., Toribio, M. D., Minguela, R., \& Aguilera, R. F. (2011). The Andalucía tourism cluster. Retrieved from http://www.isc.hbs.edu/pdf/Student_Projects/Spain_\%28Andalucia\%29_Tourism_2011.pdf

22. Marujo, M. (2005). Alqueva e a nova paisagem turística [The Alqueva and the new touristic landscape]. Revista Turismo \& Desenvolvimento, II (2), 145-148.

23. Melo, J. J. (2009). Alqueva: alegrias e frustrações da mais emblemática obra pública portuguesa do séc. $X X$ [Alqueva: joys and frustrations of the most emblematic Portuguese public works project of the XX century]. Retrieved from Repositório da Universidade de Évora. (URI: http://hdl.handle.net/10362/5096)

24. Morgan, M., Elbe, J., \& Curiel, J. E. (2009). Has the experience economy arrived? The views of destination managers in three visitor-dependent areas. International Journal of Tourism Research, 11, 201-216. doi:10.1002/jtr.719

25. Namy, S. (2007). Addressing the social impacts of large hydropower dams. The Journal of International Policy Solutions, 7, 11-17.

26. Nash R., \& Martin, A. (2003). Tourism in peripheral areas: the challenges for Northeast Scotland. International Journal of Tourism Research, 5, 161-181.

27. Neto, V. (2013). Portugal turismo - relatório urgente [Portugal Tourism - urgent report]. n.1.: Bnomics.

28. Pinto-Correia, T., Ribeiro, N., \& Sá-Sousa, P. (2011). Introducing the montado, the cork and holm oak agroforestry system of Southern Portugal. Agroforestry Systems, 82, 1, 99-104. doi:10.1007/s10457-011-9388-1

29. Pinto-Correia, T., \& Vos, W. (2004). Multifunctionality in Mediterranean landscapes - past and future. In R. Jongman (Ed.), The New Dimension of the European Landscapes (pp. 135164). Dordrecht, NL: Springer. 
30. Ribeiro, M., \& Marques, C. (2002). Rural tourism and the development of less favoured areas - between rhetoric and practice. International Journal of Tourism Research, 4 (3), 211 220.

31. Rodrigues, A. I. (2007). O Alqueva e o turismo: oportunidades, constrangimentos e desafios para um turismo de lagos [The Alqueva and tourism: opportunities, constraints and challenges for lake tourism]. Paper presented at the Congresso Internacional de Turismo Leiria e Oeste, Peniche.

32. Rosenberg, D.M., Bodaly, R.A., \& Usher, P.J. (1995). Environmental and social impacts of large scale hydroelectric development: who is listening?. Global Environmental Change, 5 (2), 127-148.

33. Saeporsdottir, A.D. (2012). Tourism and power plant development: an attempt to solve land use conflicts. Tourism Planning \& Development, 9 (4), 339-353. doi:10.1080/21568316.2012.726255

34. Saldaña, J. (2009). The coding manual for qualitative researchers. London, UK: Sage.

35. Simão, J. (2009). Turismo como motor de desenvolvimento local: o caso do Vale do Tua [Tourism as an engine for local development: the case of the Tua Valley] (Master's dissertation thesis). Universidade Nova de Lisboa, Lisbon.

36. Tedim, F., Sullivan, C., \& Estrela, M. (2009). Impacts of Alqueva dam in the region. Report of the NeWater project - new approaches to adaptive water management under uncertainty. Oxford, UK: NeWater. Retrieved from http://www.newater.uniosnabrueck.de/index.php?pid $=1020$

37. Turismo de Portugal. (2007). Plano Estratégico Nacional do Turismo [National Strategic Plan for Tourism]. Lisbon: Turismo de Portugal I.P.

38. Turismo de Portugal. (2013). Plano Estratégico Nacional do Turismo: Revisão e Objectivos 2013-2015 [National Strategic Plan for Tourism: Review and Objectives 2013-2015]. Lisbon: Turismo de Portugal I.P.

39. UNESCO/ICOMOS/AHFT. (2012). Report of the joint World Heritage Centre, ICOMOS, IUCN, Reactive monitoring mission, Alto Douro wine region (Report No. 1046). Retrieved from Agência de Desenvolvimento Regional do Vale do Tua website: http://www.valetua.pt/unesco/

40. Veiga, B., Duarte, L., \& Vasconcelos, L. (2008). A Barragem do Alqueva para quem? Por uma contextualização pluridimensional do desenvolvimento no Alentejo - Portugal [The Alqueva Dam for whom? For a multidimensional contextualization of the development in the Alentejo - Portugal]. IV Encontro da Associação Nacional de Pós-Graduação e Pesquisa em Ambiente e Sociedade, 4-6 June 2008, Brasília. Retrieved from http://www.anppas.org.br/encontro4/cd/ARQUIVOS/GT12-376-513-20080518172237.pdf

41. WCD - World Commission on Dams. (2000). Dams and development: a new framework for decision-making. London, UK: Earthscan. 